ARTICLE

DOI: $10.1038 / s 41467-018-05486-w$

\title{
Perturbation to the nitrogen cycle during rapid Early Eocene global warming
}

\author{
Christopher K. Junium (1) ${ }^{1}$, Alexander J. Dickson ${ }^{2}$ \& Benjamin T. Uveges (iD) ${ }^{1}$
}

The degree to which ocean deoxygenation will alter the function of marine communities remains unclear but may be best constrained by detailed study of intervals of rapid warming in the geologic past. The Paleocene-Eocene Thermal Maximum (PETM) was an interval of rapid warming that was the result of increasing contents of greenhouse gases in the atmosphere that had wide ranging effects on ecosystems globally. Here, we present stable nitrogen isotope data from the Eastern Peri-Tethys Ocean that record a significant transition in the nitrogen cycle. At the initiation of the PETM, the nitrogen isotopic composition of sediments decreased by $\sim 6 \%$ to as low as $-3.4 \%$, signaling reorganization of the marine nitrogen cycle. Warming, changes in ocean circulation, and deoxygenation caused a transition to nitrogen cycle to conditions that were most similar to those experienced during Oceanic Anoxic Events of the Mesozoic.

\footnotetext{
${ }^{1}$ Department of Earth Sciences, Syracuse University, Syracuse, NY 13244, USA. ${ }^{2}$ Department of Earth Sciences, Royal Holloway University of London, Egham, Surrey TW20 OEX, UK. Correspondence and requests for materials should be addressed to C.K.J. (email: ckjunium@syr.edu)
} 
$\mathrm{P}$ roductivity in the marine environment is ultimately controlled by the cycling of nitrogen, phosphorus, iron, and other bio-limiting trace elements. The degree to which nutrient cycling and marine productivity will be affected by future warming scenarios remains unclear, but the effects can be revealed through the careful investigation of past intervals of rapid warming ${ }^{1}$. One aspect of future change that has received attention is ocean deoxygenation because of its potential for serious impacts to coastal ecosystems ${ }^{2,3}$. Recent efforts aimed at quantifying the degree of $\mathrm{O}_{2}$ change in the ocean over the last 50 years have revealed significant decreases in dissolved $\mathrm{O}_{2}$ concentrations, a trend that is expected to continue ${ }^{4}$. Predicting how the nitrogen cycle might evolve in response to future oceanic redox changes is an important goal, and can be investigated from the study of rapid environmental change events in the geologic past.

The Paleocene-Eocene Thermal Maximum (PETM; 56 Ma) was the result of at least $1500 \mathrm{GT}$ of carbon and perhaps as much as 10,000 GT added to the earth-ocean-atmosphere system over less than $10 \mathrm{kyr}^{5-8}$. Carbon addition caused rapid warming of Earth's surface by $\sim 5^{\circ} \mathrm{C}$ globally ${ }^{9}$. Beyond warming, the environmental and biological consequences of rapid carbon cycle change ${ }^{10}$ have made the PETM the focus of many studies that utilize geological and paleontological records as analogues for the potential impact of future warming on marine environments. How the PETM affected nutrient cycling remains an open, and potentially important question. In an effort to help illuminate this issue, we present highly-resolved nitrogen isotope data in deposits spanning the PETM, from the northeast margin of the Tethys Ocean. The new data demonstrate that a dramatic change in the nitrogen cycle occurred during the PETM to conditions that may be similar to episodes of expanded marine anoxia known as Oceanic Anoxic Events (OAEs) that punctuated the Mesozoic greenhouse.

\section{Results}

Geologic setting. The Kheu River site is located in the Karbardino-Balkaria Republic, Russian Federation (Fig. 1). The succession was located on the northern part of the wide, shallow Peri-Tethys seaway, which was dramatically flooded starting in the Late Paleocene ${ }^{11,12}$. The base of the section is composed of calcareous mudrock of latest Paleocene age, as determined from nannofossil biostratigraphy. This unit contains a depositional hiatus that represents a flooding surface during the late-Paleocene transgression in the northern Peri-Tethys. The timing of this flooding surface is diachronous: at more northerly locations (Khazakstan), it corresponds to the base of an organic matter-rich mudrock (sapropel) level; in the southern Peri-Tethys, in the region of Kheu River, the transgressive event occurs below the sapropel level. These differences indicate sedimentary onlap in a northerly direction ${ }^{11}$.

Calcareous mudrocks at Kheu River are conformably overlain by a thin layer of organic-lean claystone that abruptly transitions into a $\sim 1 \mathrm{~m}$ thick organic matter-rich mudrock. This unit contains organic matter concentrations between 2 and $9 \mathrm{wt} \%$ total organic carbon (TOC), in two distinct TOC peaks. The base of the sapropel horizon is tied to the Paleocene-Eocene boundary by the appearance of the dinocyst Apectodinium augustum ${ }^{12,13}$, which is ubiquitous in deposits of this age (and occurs at the base of the PETM event) ${ }^{14}$. The initial $10 \mathrm{~cm}$ of the sapropel is finely laminated, above which the sapropel is occasionally bioturbated by Chondrites, an ichnofossil consistent with intermittent lowoxygen conditions at the benthic boundary layer ${ }^{13,15}$. The age of this unit also falls within nannofossil zones NP9b and $10^{13,15}$, which occur within the PETM carbon-isotope excursion at the Paleocene-Eocene GSSP at Dababiya Quarry, Egypt ${ }^{16}$. The sapropel horizon at Kheu River grades conformably into organic-lean calcareous mudstones, and eventually into siliceous mudstones at the top of the sedimentary exposure.

Paleo-depth indicators suggest a neritic depth (100-200 m) assignment for the Kheu River succession. This assignment is determined on the basis of the benthic fauna, including foraminifera with neritic depth habitats, large ostracods (requiring proximity to the photic zone), and dinocyst assemblages ${ }^{15}$. The Kheu River sapropel horizon constitutes an organic-rich unit that can be litho-, chemo-, and bio-stratigraphically correlated to

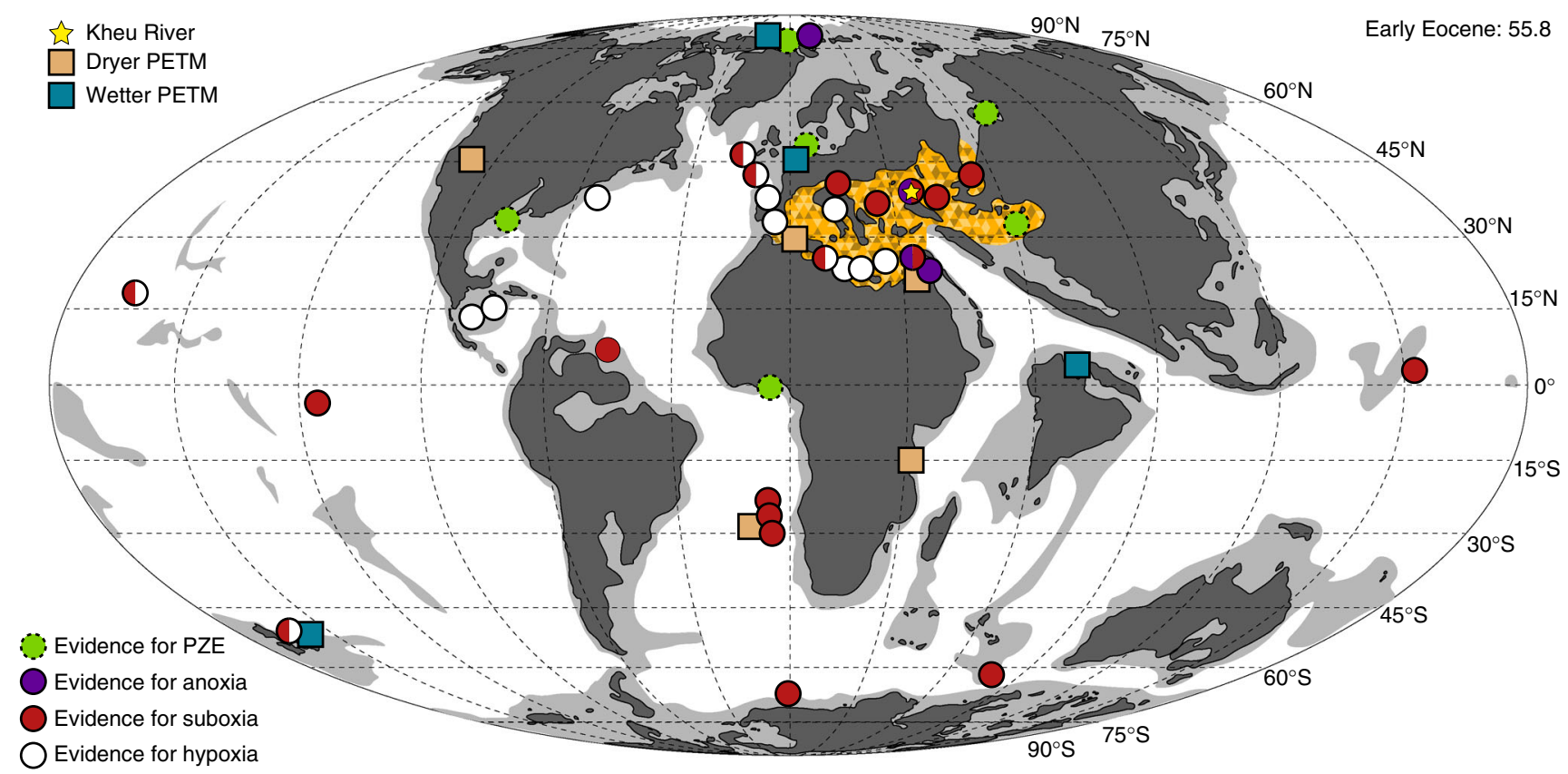

Fig. 1 Paleogeographic map of the PETM. Map adapted from plate tectonic reconstructions by Scotese ${ }^{66}$ with relevant data on redox and hydrologic indicators at PETM sites. Deoxygenation and hydrologic data from Carmichael et al. ${ }^{20}$ and references therein. Orange shaded region shows the extent of strata that displayed TOC enrichment from background during the PETM in the Tethys $11,13,16,67,68$ 


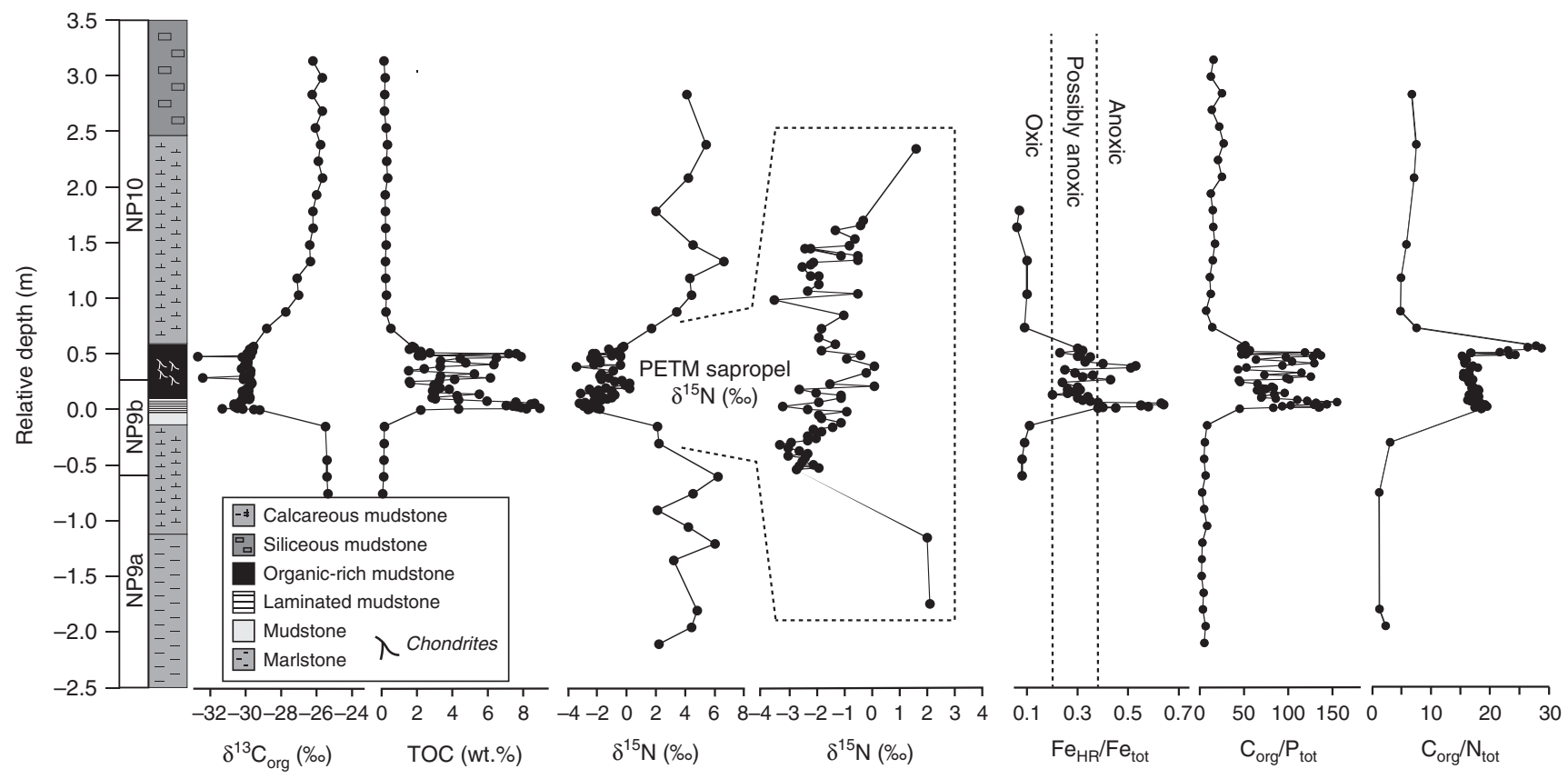

Fig. 2 Geochemical data from the Kheu River section. Primary variability in the nitrogen data reflect the facies shifts that correspond to the transitions into and out of the interval of sapropel deposition. Nitrogen-isotope data between the calcareous shales and the interbedded sapropel do not overlap, and underscore the differences in sapropel and non-sapropel geochemical conditions (Fig. 3)

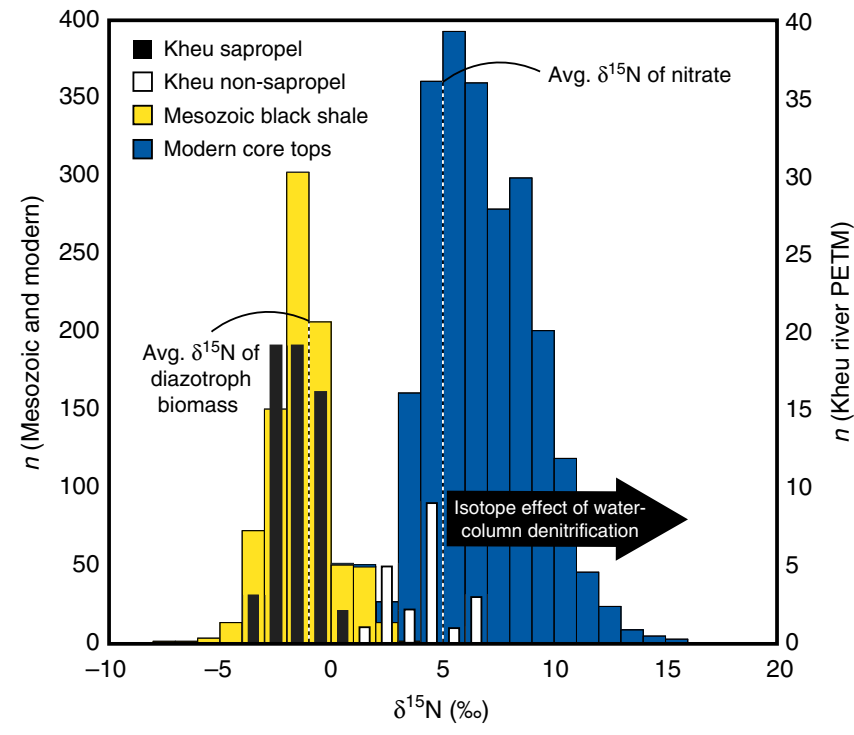

Fig. 3 Histogram of relevant nitrogen isotope data. Sedimentary nitrogen isotope data are from Kheu River, Mesozoic black shales, and modern core tops $38,41,44,48,69-73$ in $1 \%$ o bins

a large number of sites extending throughout the northern PeriTethys region, and which is consistent with a dramatic restructuring of the nutrient and redox regime to this region during the PETM.

Geochemical data. Nitrogen isotope data range from +6.2 to $+2.0 \%$ in the calcareous mudstones deposited prior to and after the PETM, and range from 0.2 to $-3.4 \%$ within the PETM sapropel (Figs. 2 and 3). $\mathrm{C} / \mathrm{N}$ ratios $\left(\mathrm{C}_{\text {org }} / \mathrm{N}_{\text {tot }}\right)$ range from 16.0 to 28.7 within the sapropel and 1.2 to 7.5 in the calcareous mudstones. Fe-speciation measurements [previously reported in Dickson et al. ${ }^{13}$ ] demonstrate highly reactive Fe to total Fe ratios $\left(\mathrm{Fe}_{\mathrm{HR}} / \mathrm{Fe}_{\mathrm{T}}\right)$ above and below the sapropel bed that are $<0.1$, consistent with deposition under oxidizing conditions. Within the sapropel, $\mathrm{Fe}_{\mathrm{HR}} / \mathrm{Fe}_{\text {tot }}$ is greater than 0.38 at the top and base of the sapropel bed, indicating predominantly anoxic depositional conditions. At the initiation of sapropel deposition the ratio of pyrite-Fe to highly reactive $\mathrm{Fe}\left(\mathrm{Fe}_{\mathrm{PY}} / \mathrm{Fe}_{\mathrm{HR}}\right)$ is $>0.8$, suggesting a brief episode of euxinia (sulfidic water column conditions). Gross variability in the geochemical data reflect the facies shifts that correspond to the transitions into and out of the interval of sapropel deposition during the PETM (Fig. 1). Nitrogen isotope data between the calcareous shales and the interbedded sapropel do not overlap (Fig. 3), and underscore the differences between sapropel and non-sapropel geochemical conditions. Comparison of geochemical parameters limited to within the sapropel bed reveals significant relationships between $\delta^{15} \mathrm{~N}$ and $\mathrm{C}_{\text {org }} / \mathrm{P}_{\text {tot }}$ and $\mathrm{C}_{\text {org }} / \mathrm{Al}_{\text {tot }}\left(\mathrm{C}_{\text {org }} / \mathrm{P}_{\text {tot }}, r^{2}=0.42, p<0.01 ; \mathrm{C}_{\text {org }} / \mathrm{Al}_{\text {tot }}, r^{2}=0.44, p<\right.$ 0.01; Supplementary Fig. 1).

\section{Discussion}

The PETM does not feature expansive deposition of organic matter-rich black shales nor is there evidence for severe deoxygenation in open marine settings in a manner that is directly analogous to the Mesozoic OAEs. Whilst there is substantial evidence that $\mathrm{O}_{2}$ content decreased in the open ocean during the PETM $^{17-19}$, severe $\mathrm{O}_{2}$ reductions were focused within the Arctic and Tethyan realms $\mathrm{s}^{20-24}$ but have been noted in other locations ${ }^{25}$. New geochemical proxies that are sensitive to differing changes in redox state paint a more nuanced picture of the degree of deoxygenation during the PETM. Iodine geochemistry indicates that $\mathrm{O}_{2}$ concentrations at intermediate water depths in open ocean settings $(1-2 \mathrm{~km})$ decreased, signaling the expansion of oxygen minimum zones (OMZs) during the PETM ${ }^{19}$. Molybdenum stable isotopes suggest that the proportion of euxinic waters, those containing free sulfide, also expanded during the PETM ${ }^{23}$. The biomarkers for phototrophic sulfide-oxidizing, green sulfur bacteria have been reported for shelf environments and provide direct evidence for euxinia in relatively shallow shelf sequences ${ }^{22,25-27}$. 

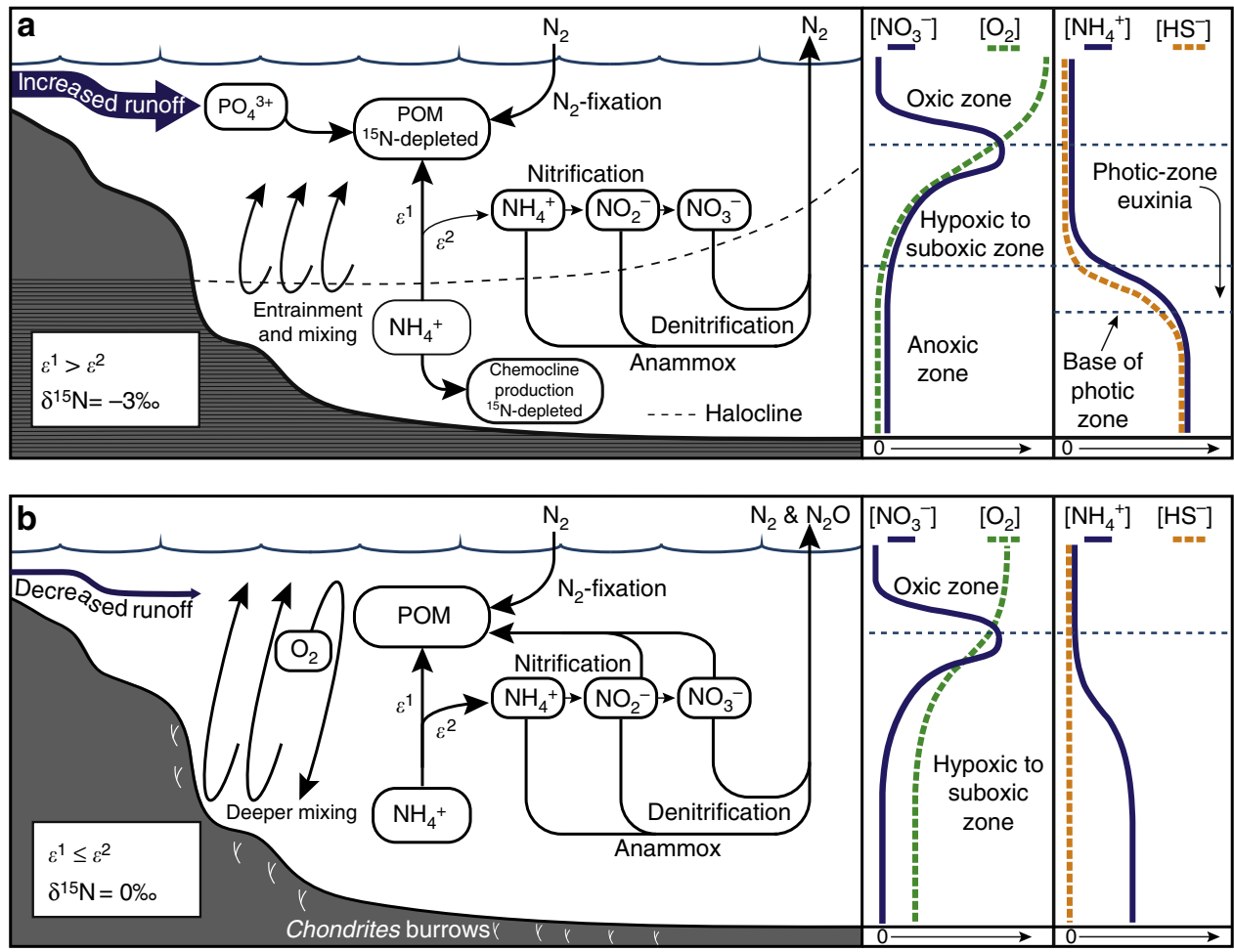

Fig. 4 Schematic diagram of the nitrogen cycle during the PETM at Kheu River. a The nitrogen cycle during the initial and late stages of the PETM when the water column was predominantly anoxic. Nitrogen isotope depletion was driven by mixing and entrainment of ammonium from below the chemocline into the lower photic zone. In this situation, high ammonium concentrations allowed for the expression of an uptake fractionation $\left(\varepsilon^{1}\right)$ by primary producers ${ }^{41}$. Less efficient utilization $\left(\varepsilon^{2}\right)$ of ammonia by nitrifying archaea and bacteria, and its subsequent reduction to $\mathrm{N}_{2}$ via denitrification and anammox serve as a sink for residual ${ }^{15} \mathrm{~N}$-enriched ammonium. b During the middle interval of the PETM at Kheu River, deeper mixing allowed for invasion of $\mathrm{O}_{2}$ to the benthic boundary layer, development of suboxic/hypoxic conditions that may have allowed for the production of $\mathrm{N}_{2} \mathrm{O}$ and relative ${ }^{15} \mathrm{~N}$-enrichment

The expansion of euxinia ${ }^{23}$ and increased organic carbon burial in coastal environments ${ }^{28}$ highlight the interplay between the flux of weathering-derived nutrients and the hydrography of shelf systems. Bursts of nutrient-rich fresh water into coastal systems in an intensifying hydroclimate ${ }^{29}$ might have been sufficient to drive short-term reductions in water column oxygen content as organic matter export increased. However, the more pronounced anoxia that occurred over wide regions of Eastern Peri-Tethys during the PETM $^{11}$ (Fig. 1) required longer-term changes in the style of regional circulation and/or nutrient availability. Gavrilov et al. ${ }^{11}$ hypothesize that the combined effect of transgression and an increased flux of riverine-derived nutrients were the likely mechanisms that set the stage for sapropel deposition in the Eastern Tethys. Epicontinental basins similar to the Eastern Tethys, such as the Laurentian basins of the Late Devonian $^{30}$ and Cretaceous Western Interior Seaway ${ }^{31}$ maintained estuarine modes of circulation that fostered periods of black shale deposition. During the PETM in the Eastern PeriTethys, a regionally wetter hydroclimate ${ }^{20}$ coupled with transgression might have supported an estuarine circulation where less saline surface waters limited ventilation of more saline deepwaters. Despite the development of halostratification, estuarine circulation regimes are by no means stagnant. Rather, surface waters entrain and mix with anoxic, nutrient-rich deep waters while maintaining a dynamic chemostratification (Fig. 4).

Basinal anoxia, and euxinia in particular, enhance the accumulation of ammonium and phosphate derived from degraded organic matter within the anoxic region of the water column ${ }^{32}$. Significant increases in $\mathrm{C}_{\text {org }} / \mathrm{P}_{\text {tot }}$ ratios in the Kheu River (Fig. 2) section $^{13}$ are consistent with this liberation of $\mathrm{P}$ from organic matter and sedimentary mineral phases ${ }^{33}$. Shallowing of the chemocline to an extent that allowed for expansion of photic zone euxinia during the PETM at Kheu River ${ }^{12}$ suggests that high nutrient concentrations were available to photoautotrophs as well as chemocline dwellers. Despite the extremes of anoxia experienced at Kheu River, evidence for bioturbation within the sapropel level indicates that there were significant oscillations in redox state. In this relatively shallow environment, relaxation of stratification and oxidation of the benthic boundary layer would have been accompanied by mixing of deep water nutrients to the surface, stimulating productivity. Here, we consider how the nitrogen isotopic record from Kheu River can illuminate the interaction between local nutrient dynamics and redox state, and serve as a point of perspective to more thoroughly consider the extent of nitrogen cycle perturbation during the PETM.

Nitrogen isotopes of organic matter from marine sediments provide a means for disentangling nitrogen cycle processes ${ }^{34}$. In particular, nitrogen isotopes are sensitive to changes in local water column redox state. The isotopic composition and reservoir size of dissolved inorganic nitrogen (DIN: $\mathrm{NO}_{3}{ }^{-}, \mathrm{NO}_{2}{ }^{-}$, and $\mathrm{NH}_{4}{ }^{+}$) reflect the relative influences of the principal nitrogen cycle processes. Biological nitrogen fixation (diazotrophy) serves as the primary input of new nitrogen to the ocean. The organic matter produced by diazotrophs has an isotopic composition that is pinned to the $\delta^{15} \mathrm{~N}$ of the atmosphere with a minor fractionation that results in organic matter that is approximately $-1 \%$ 35 . Anaerobic respiratory processes that reduce nitrate and nitrite $\left(\mathrm{NO}_{3}{ }^{-}\right.$and $\left.\mathrm{NO}_{2}{ }^{-}\right)$to $\mathrm{N}_{2}$ or $\mathrm{N}_{2} \mathrm{O}$, occur in the low- $\mathrm{O}_{2}$ regions of the water column or within sediment pore waters, and constitute the most important sinks for nutrient nitrogen ${ }^{36}$. The biological isotope effect $(\varepsilon)$ of nitrate reduction, inclusive of both denitrification and anaerobic ammonium oxidation (anammox) 
processes, is significant $(\varepsilon=10-30)$, and results in ${ }^{15} \mathrm{~N}$ enrichment of the residual nitrate, in some cases to as high as $+15 \%{ }^{34,37}$. The relative balance between diazotrophy and water column nitrate reduction is integrated by the average $\delta^{15} \mathrm{~N}$ of deep water $\mathrm{NO}_{3}{ }^{-}$in the modern ocean which is $\sim+5 \% 0^{37}$.

The water column nitrogen cycle signals imparted on DIN can be reliably traced in the $\delta^{15} \mathrm{~N}$ of modern core top sedimentary organic matter. However, demonstrating that nitrogen isotope signals in sedimentary organic matter are reflective of water column processes has been an important hurdle in deep time paleoceanography. The $\delta^{15} \mathrm{~N}$ of bulk sediments from modern environments, particularly under reducing conditions, preserve the isotopic composition of water column particulate biomass and sub-euphotic zone $\mathrm{DIN}^{38-40}$. In more ancient sedimentary sequences, bulk $\delta^{15} \mathrm{~N}$ has been shown to be a faithful recorder of water column processes where thermal maturities are low. Further confirmation of the fidelity of bulk $\delta^{15} \mathrm{~N}$ in ancient organicmatter-rich sediments has also been demonstrated through kerogen and compound-specific $\delta^{15} \mathrm{~N}$ analyses of chlorophyll $a$ derived porphyrins. These studies demonstrate that even anomalously low nitrogen isotopic signatures in Cretaceous black shales reflect the $\delta^{15} \mathrm{~N}$ of oxygenic photoautotrophic biomass, and are similar to those we observe in the Kheu river section ${ }^{41-43}$ (Fig. 3).

In consideration of the Kheu River nitrogen isotope record, it is unlikely that oxidation, organic matter mixing, or thermal maturity played a strong role in controlling the $\delta^{15} \mathrm{~N}$ signatures during sapropel deposition. The organic geochemistry of the Kheu sapropel suggests that organic nitrogen was thermally immature and derived from a predominantly marine source of organic matter ${ }^{13,15}$. Terrestrially-derived organic matter is present throughout the section but contributed a relatively minor proportion of the total organic-matter ${ }^{13,15}$. The relationship between $\mathrm{N}(\mathrm{wt} \%)$ and TOC (wt\%) within the sapropel is very strong $\left(R^{2}=0.97 ; p \ll 0.01\right)$ (Supplementary Fig. 2$)$, and suggests that organic nitrogen is dominated by one source, without significant influence from nitrogen of detrital origin or other sources with significantly different $\mathrm{C} / \mathrm{N}$ ratios. The elevated $\mathrm{C} / \mathrm{N}$ ratios that we observe in the Kheu sapropel are typical of Phanerozoic black shales and sapropels, and are attributed to enhanced preservation of organic carbon, and relative loss of ammonium-N from sediments due to a limitation in the sorptive capacity of mineral surfaces ${ }^{44,45}$.

Prior to and following the PETM, oxic conditions prevailed during deposition of the calcareous mudrocks under and overlying the sapropel (Fig. 2). The relatively enriched $\delta^{15} \mathrm{~N}(+1.7$ to $+6.6 \%$ ) in the calcareous mudrocks are typical of modern shelf settings that have oxic water columns ${ }^{38}$ (Fig. 3). Oxidizing conditions can be conducive to the preferential degradation of organic nitrogen, and alteration of $\delta^{15} \mathrm{~N}$ may have occurred. Detailed investigations of the effect of degradation of organic $\delta^{15} \mathrm{~N}$ in oxic sediments have demonstrated an increase in the order of $1 \%$ in organic nitrogen ${ }^{45}$. Despite the range of potential issues, the total effect on bulk $\delta^{15} \mathrm{~N}$ is limited ${ }^{40,46}$. In the Holocene of the eastern Mediterranean, $\delta^{15} \mathrm{~N}$ oscillations of up to $8 \%$ have been reported between sapropels and organic lean marls (wt $\%$ TOC $<0.25 \%$ ), a signal that has been confirmed by compoundspecific $\delta^{15} \mathrm{~N}$ analyses of chlorophyll derivatives ${ }^{47}$. This similarity suggests that even in the deep eastern basin of the Mediterranean (depth $>1000 \mathrm{~m}$ ) the oxic degradation of organic nitrogen had an inconsequential effect on the $\delta^{15} \mathrm{~N}$ of bulk sediments. Accordingly, the $\delta^{15} \mathrm{~N}$ of bulk sediments from the calcareous claystones of the Kheu River section are likely to be reasonable approximations of primary organic material.

At the onset of the PETM, the sharp decrease in $\delta^{15} \mathrm{~N}$ was maintained for the duration of sapropel deposition and the PETM carbon isotope excursion (average $=-1.64 \% ; 1 \sigma=0.88 n=59$ ). The $\delta^{15} \mathrm{~N}$ minimum of $-3.6 \%$ and distribution of $\delta^{15} \mathrm{~N}$ data are strikingly similar to black shales deposited during Mesozoic $\mathrm{OAEs}^{48}$ (Fig. 3). The few nitrogen isotope records from the PETM where organic matter is present in sufficient quantities to be certain of an autochthonous source ${ }^{49}$ are limited to sites from the southern Tethys and the Arctic Basin where bulk $\delta^{15} \mathrm{~N}$ is not lower than $0 \%{ }^{8,50}$. Nitrogen isotopic compositions that are significantly less than $0 \%$ in marine settings are largely unique to organic matter-rich sediments and mudrocks from Mediterranean sapropels and Mesozoic black shales (Fig. 3). This association suggests that the processes that controlled the nitrogen cycle during the PETM in the Eastern Tethys and during Phanerozoic OAEs may have shared similar biogeochemical mechanisms.

Nitrogen isotopic compositions that are significantly less than the nitrogen fixation end member $\left(\delta^{15} \mathrm{~N}<-1 \%\right.$ o require a unique set of circumstances. The favored explanation for this degree of ${ }^{15} \mathrm{~N}$-depletion relies upon the mixing of ammonium into the photic zone in excess of biochemical need, allowing for expression of the uptake fractionation by phytoplankton during ammonium assimilation ${ }^{41}$. The problem with ${ }^{15} \mathrm{~N}$-depletion to this extent is that it requires a sink for the residual ${ }^{15} \mathrm{~N}$-enriched ammonium that is in excess after assimilation. In the absence of this sink, complete utilization of ammonium would result in biomass $\delta^{15} \mathrm{~N}$ equivalent to the $\delta^{15} \mathrm{~N}$ of the ammonium available to phytoplankton.

Higgins et al. ${ }^{41}$ proposed a biochemical mechanism that hinges on the isotopic partitioning of the ammonium between phytoplankton and ammonia-oxidizing bacteria and archaea on the basis of differences in the magnitude of biological fractionation $(\varepsilon)$ and rate of uptake $(\varphi)$ between the two communities. When $\varepsilon$ for ammonium assimilation by phytoplankton is greater than that of ammonia oxidation, the $\delta^{15} \mathrm{~N}$ of sinking organic matter is lower than the $\delta^{15} \mathrm{~N}$ of ammonium (Fig. 4). The fate of the residual oxidized ammonium (nitrate and nitrite) is key to this model: it must be reduced by denitrifiers and anammox bacteria and lost as $\mathrm{N}_{2}$ or $\mathrm{N}_{2} \mathrm{O}$. Anammox and denitrification served as a terminal sink for the residual, relatively ${ }^{15} \mathrm{~N}$-enriched nitrate and nitrite. The presence of ammonium can also limit the expression of the genes that encode for the membrane transport and assimilatory reduction of nitrate by phytoplankton ${ }^{51}$. Repression of nitrate assimilation would further favor the utilization of ammonium when available to oxygenic photoautotrophs, leaving nitrate and nitrite available for dissimilatory reduction by denitrifiers and anammox bacteria.

Accumulation of an ammonium reservoir is a precondition for the ${ }^{15} \mathrm{~N}$-depletion that we observe in the Kheu sapropel. The geologic and geochemical evidence for persistent nutrient trapping and ammonium-rich deep waters at Kheu River is strong. Modern anoxic marine basins where ammonium concentrations are $>5 \mu \mathrm{M}$ are accompanied by measurable concentrations of sulfide $^{52,53}$. Biomarker data indicating photic zone euxinia in the Eastern Peri-Tethys ${ }^{26}$ suggest that sulfide was at least episodically present within the photic zone. The $\delta^{15} \mathrm{~N}$ minimum in the lowermost $10 \mathrm{~cm}$ of finely laminated sapropel at the initiation of the PETM occurs where \%TOC, $\mathrm{C}_{\text {org }} / \mathrm{P}_{\text {tot }}, \mathrm{C}_{\text {org }} / \mathrm{Al}_{\text {tot }}$ (Fig. 2), trace metal enrichments and lycopane/n-C35 alkane indices are the highest, suggesting severe anoxia. Fe-speciation data ${ }^{13}$ are also consistent with anoxic and euxinic conditions during the later stages of sapropel deposition when $\delta^{15} \mathrm{~N}$ values are also lower than $-2 \%$ o (Fig. 2).

The paleoceanographic mechanism for the overall ${ }^{15} \mathrm{~N}$ depletion is consistent with a shift in the style of circulation during the PETM in the Eastern Peri-Tethys. Transgression, intensification of the hydrologic cycle and an increased flux of fresh water from Eurasia delivered weathering-derived nutrients 
and maintained an estuarine style of circulation. It should be noted that this mechanism does not require substantial reductions in surface water salinities, which are not supported by the microfossil record ${ }^{15}$. Rather, the dynamical response of relatively enclosed bodies of water to an increased freshwater flux from land can induce estuarine circulation with relatively small variations in salinities ${ }^{31}$. The net effect of circulation changes during the PETM in the Tethys enhanced nutrient trapping, increased productivity, and a led to a shallow chemocline ${ }^{20}$ (Fig. 4). Throughout the PETM, a significant relationship between $\mathrm{C}_{\text {org }} /$ $\mathrm{P}_{\text {tot }}$ and $\mathrm{C}_{\text {org }} / \mathrm{Al}_{\text {tot }}$ with $\delta^{15} \mathrm{~N}$ (Supplementary Fig. 1) suggests that nutrient recycling played a fundamental role in maintaining productivity, anoxia, and the flux of ammonium from deeper waters. Additionally, higher phosphate availability may have enhanced nitrogen fixation, to some degree, lowering the overall $\delta^{15} \mathrm{~N}$ of DIN.

Following the initial deposition of the sapropel level, with $\delta^{15} \mathrm{~N}$ of $-3.2 \%$, $\delta^{15} \mathrm{~N}$ increased to $+0.5 \%$. Coincident with ${ }^{15} \mathrm{~N}$ enrichment, Fe-speciation indicates more oxidizing conditions, and \%TOC, $\mathrm{C}_{\text {org }} / \mathrm{P}_{\text {tot }}$, and $\mathrm{C}_{\text {org }} / \mathrm{Al}_{\text {tot }}$ decrease. At least episodically oxidizing conditions at the benthic boundary layer are indicated by the occurrence of Chondrites burrows ${ }^{15,54}$ and a lack of sedimentary laminae. Collectively, these data suggest that the stratification and euxinia at the initiation of the PETM waned, allowing ventilation of the benthic boundary layer. A potential mechanism for this transition may lie in terrestrial sequences of the Pyrenees ${ }^{29}$ where fluvial sedimentology demonstrates a clear shift toward significantly higher discharges with extreme seasonality in the early stages of the PETM, but this effect is not persistent. If enhanced riverine nutrient flux, estuarine circulation, and relative sea level variations ${ }^{12,13,15}$ were the primary controls of sapropel development, as we suggest, a similar climatic regime apparently operated in the region of Kheu River in the Eastern Peri-Tethys. The initial stage of enhanced stratification, anoxia, and ${ }^{15} \mathrm{~N}$-depletion was coincident with the rapid decrease in $\delta^{13} \mathrm{C}$ at the onset of the PETM (Fig. 2). The later interval of ${ }^{15} \mathrm{~N}$-depletion and renewed anoxia that occurred near the termination of the plateau phase of the PETM likely has a similar mechanism: an enhanced riverine flux that maintained stratification and provided nutrients (Fig. 2). Hydroclimate perturbations at the initiation of the PETM are well-known ${ }^{29}$, but the later reinvigoration of anoxia at Kheu River may be linked to regional fluctuations in relative sea-level and weathering ${ }^{15}$.

The interval of reduced stratification during the middle of the PETM at Kheu River would have increased the volume of low- $\mathrm{O}_{2}$ hypoxic or suboxic waters at the expense of anoxic water (hypoxia is where $\mathrm{O}_{2}$ concentrations are between 1 and $30 \%$ saturation and suboxia where $\mathrm{O}_{2}<1 \%$ saturation $)^{55}$. A transition from fully anoxic conditions to suboxic conditions would have stimulated the activity of dissimilatory nitrogen redox metabolisms; ammonia oxidation (nitrification), nitrate/nitrite reduction, and anammox ${ }^{56}$. The increase in $\delta^{15} \mathrm{~N}$ that occurred over this interval of time may signal the ${ }^{15} \mathrm{~N}$-enrichment of DIN that can accompany these processes. While the magnitude of the $\delta^{15} \mathrm{~N}$ excursion is equivalent to the increase in denitrification related to postPleistocene warming ${ }^{38}$, a $\delta^{15} \mathrm{~N}$ of $+0.5 \%$ is not typically considered to be indicative of water column denitrification and may only reflect a reduction in the utilization of ammonium by phytoplankton and low $\delta^{15} \mathrm{~N}$ of DIN sourced primarily by diazotrophs.

At Kheu River and elsewhere in the Eastern Peri-Tethys, the development of hypoxic or suboxic conditions during the PETM had the potential to induce positive feedbacks on a rapidly warming world. Nitrous oxide is one of the products of denitrification and ammonia oxidation by bacteria ${ }^{57}$ and archaea ${ }^{58}$ and is a potent greenhouse gas. In the modern ocean at least one-third of the global nitrous oxide flux to the atmosphere is sourced from oxygen-deficient marine waters ${ }^{59}$, and hypoxic and suboxic conditions in shallow shelf sequences are hot spots for nitrous oxide production and its escape to the atmosphere ${ }^{55,60}$. Pulses of oxic waters into the anoxic Gotland Basin in the Baltic Sea have been accompanied by significant increases in the local production of nitrous oxide ${ }^{61}$ and a similar system may have operated at Kheu River. The transition from anoxic to hypoxic/ suboxic conditions at Kheu River during the PETM may have stimulated nitrous oxide production, and the expansion of oxygen-deficient waters globally ${ }^{20}$ may have had a similar effect. The degree to which nitrous oxide production operated at a level that impacted PETM warming is unknown, but worthy of more detailed future study.

The PETM bears many of the hallmarks that define OAEs ${ }^{62}$. Over the course of the PETM, warming induced a broad expansion of reducing conditions $s^{13,19,20,23}$ and our data suggest a significant reorganization of the nitrogen cycle in response to these redox changes at Kheu River. Unlike many Mesozoic OAEs, PETM organic-matter-rich deposition was entirely confined to shelves and relatively enclosed basins. We speculate that this difference is the result of basin geometries and circulation patterns during the PETM that were less well-suited to broader development of organic matter-rich deposition. During some Mesozoic events, such as Oceanic Anoxic Event 2 ( $94 \mathrm{Ma}$ ), estuarine circulation and nutrient trapping in the Atlantic and Tethys Oceans nurtured black shale deposition on shelves and deep basins over long periods of time ${ }^{63}$. Despite these differences, the Tethys during the PETM had geochemical conditions, including the nitrogen isotope record, which were essentially indistinguishable from Mesozoic OAEs (Fig. 3).

Today, near-shore regions are clearly sensitive to nutrient loading ${ }^{2}$. Coastal anoxia is exacerbated by the direct addition of nutrients from human activities ${ }^{60}$, but the compounding effects of warming over the coming centuries on near-shore regions is hard to predict. For this reason we look to the geologic record as an analogue, for which the PETM serves as the most recent example of rapid, $\mathrm{CO}_{2}$-driven global warming in a non-glacial climatic state $^{1}$. It is clear that near-shore regions in some parts of the Early Eocene world experienced extreme environmental shifts. Given the fact that the rate of PETM warming was likely significantly slower $^{8}$ than present-day warming, the consequences of anthropogenic climate change on biogeochemical systems may be extreme. This argument underscores the sensitivity of modern coastal ecosystems to the consequences of rapid climate change.

\section{Methods}

Nitrogen isotope analyses. Nitrogen isotopic analyses of decarbonated rock powders were performed in the Syracuse University GAPP Lab using an Elementar Isotope Cube elemental analyzer (EA) coupled directly to an Isoprime 100 isotope ratio mass spectrometer (IRMS) when using conventional techniques for EAIRMS. EA conditions were as follows: helium purge was set for $45 \mathrm{~s}$, oxidation and reduction reactor temperatures were $1100^{\circ} \mathrm{C}$ and $650^{\circ} \mathrm{C}$, respectively; helium carrier gas flow was $230 \mathrm{ml} / \mathrm{min}$; and the $\mathrm{O}_{2}$ pulse was set for $90 \mathrm{~s}$ at a flow rate of $25 \mathrm{ml} / \mathrm{min}$. Reproducibility for replicate samples, in-house standard materials and international reference materials (IAEA N1 ammonium sulfate $[+0.4 \%$ o, $\mathrm{N} 2$ ammonium sulfate [ $+20.3 \%$ ] , NIST 1547 peach leaves $[+2.0 \%$ o]; and Messel Oil Shale $[+7.0 \%$ o $]$ ) was often better than $\pm 0.15 \%$ o, but are reported as $\pm 0.2 \%$ o to reflect the known nitrogen isotopic composition of reference materials relative to atmospheric $\mathrm{N}_{2}[0 \%$ ]

Conventional nitrogen isotopic analyses of organic-matter-rich sediments with high $\mathrm{C} / \mathrm{N}$ can prove difficult. Sample $\mathrm{CO}_{2}$ carryover into subsequent samples is the most significant concern and can generate neoformed $\mathrm{CO}^{+}$within the ion source resulting in significant ${ }^{15} \mathrm{~N}$-depletion. Despite the organic richness of these samples, the low thermal maturity allowed for complete combustion indicated by clean blanks and accuracy of interspersed reference materials. As well, the trap and purge system for $\mathrm{CO}_{2}$ analysis in the Elementar Isotope EA traps any $\mathrm{CO}$ or residual $\mathrm{CO}_{2}$ from the previous sample. The possibility of $\mathrm{CO}$ generation during the course of sample runs is further achieved by observing $\mathrm{m} / z 30$ during $\mathrm{N}_{2}$ elution which indicates the co-elution of ${ }^{12} \mathrm{C}^{18} \mathrm{O}$; the presence of the more 
abundant ${ }^{12} \mathrm{C}^{16} \mathrm{O}$ is masked by at $\mathrm{m} / z 28$ by $\mathrm{N}_{2}$ but can the cause of anomalous ${ }^{15} \mathrm{~N}$-depletion.

Nitrogen isotope analyses employing nanoEA. Alternative methods for analysis of the nitrogen isotopic composition of Kheu Rivers samples was employed for samples where the available material was extremely limited, or where organic carbon content was below $0.5 \mathrm{wt} \%$. The "nanoEA" method that we employed was similar to that described in Polissar et al. ${ }^{64}$. The nanoEA comprises an Elementar Isotope Cube EA coupled to an Isoprime Trace Gas analyzer. The Trace Gas is used for $\mathrm{N}_{2}$ trapping and chromatographic focusing prior to sample gas introduction into the Isoprime 100 stable isotope mass spectrometer. Sample powders were loaded into tin capsules, evacuated, and purged with argon prior to introduction into the EA to remove interstitial atmospheric $\mathrm{N}_{2}$. EA conditions were as follows: helium purge was set for $45 \mathrm{~s}$, oxidation and reduction reactor temperatures were 1100 and $650^{\circ} \mathrm{C}$, respectively; helium carrier gas flow was $150 \mathrm{ml} / \mathrm{min}$; and the $\mathrm{O}_{2}$ pulse was set for $90 \mathrm{~s}$. During sample analyses, the full flow of the EA is diverted to an automated silica gel-filled cryotrap that is immersed in liquid nitrogen over the duration that $\mathrm{N}_{2}$ gas is generated during sample combustion. The $\mathrm{N}_{2}$ trap is switched to a low-flow He carrier gas $(2 \mathrm{ml} / \mathrm{min})$ via an automated Vici 6-port Valco valve and released to the IRMS through an Agilent CarboBond column $(25 \mathrm{~m} \times 0.53 \mathrm{~mm} \times 5 \mu \mathrm{m})$.

NanoEA Samples were run in triplicate using sequentially larger samples (i.e., 2 , 4 , and $6 \mathrm{mg}$ ) and blank corrected using Keeling-style plots. International reference materials IAEA N1 ammonium sulfate $[+0.4 \%$ o], $\mathrm{N} 2$ ammonium sulfate $[+20.3 \%$ ] , NIST 1547 peach leaves $[+2.0 \%$ o]; and Messel Oil Shale $[+7.0 \%$ o] were run in a similar manner, and in quantities of $\mathrm{N}$ that bracketed the $\mathrm{N}$-content of the sample materials. The resulting blank corrected sample and standard data were corrected to accepted values for the reference materials using the correction scheme described in Coplen et al. ${ }^{65}$. Reproducibility for samples and standards using nanoEA is $\pm 0.25 \%$, and approaches the reported nitrogen isotopic composition of the reference materials $( \pm 0.2 \%)$. Standard EA-IRMS techniques reproducibility was better than $\pm 0.2 \%$.

Data availability. All data considered in the manuscript are provided in the Supplementary Information that accompanies this manuscript.

Received: 26 October 2017 Accepted: 28 June 2018

Published online: 09 August 2018

\section{References}

1. Pancost, R. D. Climate change narratives. Nature 10, 466-468 (2017).

2. Diaz, R. J. \& Rosenberg, R. Spreading dead zones and consequences for marine ecosystems. Science 321, 926-930 (2008).

3. Keeling, R. F., Arne, K. \& Gruber, N. Ocean deoxygenation in a warming world. Annu. Rev. Mar. Sci. 2, 199-229 (2010).

4. Schmidtko, S., Stramma, L. \& Visbeck, M. Decline in global oceanic oxygen content during the past five decades. Nature 542, 335-339 (2017).

5. Zeebe, R. E., Zachos, J. C. \& Dickens, G. R. Carbon dioxide forcing alone insufficient to explain Palaeocene-Eocene Thermal Maximum warming. Nat. Geosci. 2, 576-580 (2009).

6. Kirtland-Turner, S., Hull, P. M., Kump, L. R. \& Ridgwell, A. A probabilistic assessment of the rapidity of PETM onset. Nat. Commun. 8, 353 (2017).

7. Gutjahr, M. et al. Very large release of mostly volcanic carbon during the Palaeocene-Eocene Thermal Maximum. Nature 548, 573-577 (2017).

8. Cui, Y. et al. Slow release of fossil carbon during the palaeocene-eocene thermal maximum. Nat. Geosci. 4, 481-485 (2011).

9. Dunkley, T. et al. Climate model and proxy data constraints on ocean warming across the Paleocene-Eocene Thermal Maximum. Earth Sci. Rev. 125, 123-145 (2013)

10. Wing, S. L. et al. Transient floral change and and rapid global warming at the Paleocene-Eocene Boundary. Science 310, 993-996 (2005).

11. Gavrilov, Y., Kodina, L. A., Lubchenko, I. Y. \& Muzylöv, N. G. The late Paleocene anoxic event in epicontinental seas of Peri-Tethys and formation of sapropelite unit: sedimentology and geochemistry. Lithol. Miner. Resour. 35, 427-450 (1997).

12. Gavrilov, Y. O., Shcherbinina, E. A. \& Oberhänsli, H. Paleocene-Eocene boundary events in the northeastern Peri-Tethys. Geol. Soc. Am. Spec. Pap. 369, 147-168 (2003).

13. Dickson, A. J. et al. The spread of marine anoxia on the Northern Tethys margin during the Paleocene-Eocene Thermal Maximum. Paleoceanography. https://doi.org/10.1002/2014PA002629 (2014).

14. Crouch, E. M. et al. The Apectodinium acme and terrestrial discharge during the Paleocene-Eocene thermal maximum: new palynological, geochemical and calcareous nannoplankton observations at Tawanui, New Zealand. Palaeogeogr. Palaeoclimatol. Palaeoecol. 194, 387-403 (2003).
15. Shcherbinina, E. et al. Environmental dynamics during the Paleocene-Eocene thermal maximum (PETM) in the northeastern Peri-Tethys revealed by highresolution micropalaeontological and geochemical studies of a Caucasian key section. Palaeogeogr. Palaeoclimatol. Palaeoecol. 456, 60-81 (2016).

16. Aubry, M. P., Ouda, K., Dupuis, C., Berggren, W. A. \& Van Couvering, J. A. The Global Standard Stratotype-section and Point (GSSP) for the base of the Eocene Series in the Dababiya section (Egypt). Episodes 30, 271-286 (2007).

17. Bralower, T. J. et al. High-resolution records of the late Paleocene thermal maximum and circum-Caribbean volcanism: is there a causal link? Geology. 25, 963-966 (1997)

18. Chun, C. O. J., Delaney, M. L. \& Zachos, J. C. Paleoredox changes across the Paleocene-Eocene thermal maximum, Walvis Ridge (ODP Sites 1262, 1263, and 1266): evidence from Mn and U enrichment factors. Paleoceanography $\mathbf{2 5}$, $1-13$ (2010)

19. Zhou, X., Thomas, E., Rickaby, R. E. M., Winguth, A. M. E. \& Lu, Z. I/Ca evidence for upper ocean deoxygenation during the PETM. Paleoceanography 29, 964-975 (2014)

20. Carmichael, M. J. et al. Hydrological and associated biogeochemical consequences of rapid global warming during the Paleocene-Eocene Thermal Maximum. Glob. Planet. Change 157, 114-138 (2017).

21. Speijer, R. P. \& Wagner, T. Sea-level changes and black shales associated with the late Paleocene thermal maximum: organic-geochemical and micropaleontologic evidence from the southern Tethyan margin (Egypt-Israel). Geol. Soc. Am. Spec. Pap. 356, 533-549 (2002).

22. Sluijs, A. et al. Subtropical Arctic Ocean temperatures during the Palaeocene/ Eocene thermal maximum. Nature 441, 3-6 (2006)

23. Dickson, A. J., Cohen, A. S. \& Coe, A. L. Seawater oxygenation during the Paleocene-Eocene Thermal Maximum. Geology. 40, 639-642 (2012).

24. Dickson, A. J., Cohen, A. S. \& Coe, A. L. Continental margin molybdenum isotope signatures from the Early Eocene. Earth Planet. Sci. Lett. 404, 389-395 (2014).

25. Sluijs, A. et al. Warming, euxinia and sea level rise during the Paleocene-Eocene Thermal Maximum on the Gulf Coastal Plain: implications for ocean oxygenation and nutrient cycling. Clim. Past. 10, 1421-1439 (2014).

26. Kodina, L. A., Huang, Y., Gavrilov, Y. O., Jones, M. \& Eglinton, G. Environment of upper Paleocene black shale deposition in Southern Russia and adjacent regions as revealed by isotope and biomarker study. In Organic Geochemistry: Developments and Applications to Energy, Climate, Environment and Human History: Selected Papers from the 17th International Meeting on Organic Geochemistry, Special Papers 369, 192-194 (1995).

27. Frieling, J. et al. Extreme warmth and heat-stressed plankton in the tropics during the Paleocene-Eocene Thermal Maximum. Sci. Adv. 3, e1600891 (2017).

28. John, C. M. et al. North American continental margin records of the Paleocene-Eocene thermal maximum: implications for global carbon and hydrological cycling. Paleoceanography 23, 1-20 (2008).

29. Schmitz, B. \& Pujalte, V. Abrupt increase in seasonal extreme precipitation at the Paleocene-Eocene boundary. Geology 35, 215-218 (2007).

30. Algeo, T. J., Heckel, P. H., Maynard, J. B., Blakey, R. \& Rowe, H. Modern and ancient epicratonic seas and the superestuarine circulat ion model of marine anoxia. In Dynamics of Epeiric Seas: Sedimentological, Paleontological and Geochemical Perspectives: Geological Association of Canada Special Publications 48, 7-38 (2008).

31. Slingerland, R. I. et al. Estuarine circulation in the Turonian Western Interior seaway of North America. Geol. Soc. Am. Bull. 108, 941-952 (1996).

32. Meyer, K. M. \& Kump, L. R. Oceanic Euxinia in Earth history: causes and consequences. Annu. Rev. Earth Planet. Sci. 36, 251-288 (2008).

33. Ingall, E. \& Jahnke, R. Evidence for enhanced phosphorus regeneration from marine sediments overlain by oxygen depleted waters. Geochim. Cosmochim. Acta 58, 2571-2575 (1994).

34. Galbraith, E. D., Sigman, D. M., Robinson, R. S. \& Pedersen, T. F. in Nitrogen in the Marine Environment 2nd edn (eds Capone, D. G., Bronk, D. A., Mulholland, M. R. \& Carpenter, E. J.) 1497-1535 (Academic Press, 2008).

35. Bauersachs, T. et al. Nitrogen isotopic fractionation associated with growth on dinitrogen gas and nitrate by cyanobacteria. Limnol. Oceanogr. 54, 1403-1411 (2009).

36. Ren, H. et al. Foraminiferal isotope evidence of reduced nitrogen fixation in the Ice Age Atlantic Ocean. Science 323, 244-248 (2009).

37. Sigman, D. M., Karsh, K. L. \& Casciotti, K. L. in Encyclopedia of Ocean Sciences (ed. Steele, J. H.) 40-54 (Elsevier, 2009).

38. Galbraith, E. D. et al. The acceleration of oceanic denitrification during deglacial warming. Nat. Geosci. 6, 579-584 (2013).

39. Altabet, M. A. et al. The nitrogen isotope biogeochemistry of sinking particles from the margin of the Eastern North Pacific. Deep Sea Res. I 46, 655-679 (1999).

40. Robinson, R. S. et al. A review of nitrogen isotopic alteration in marine sediments. Paleoceanography 27, 1-18 (2012).

41. Higgins, M. B., Robinson, R. S., Husson, J. M., Carter, S. J. \& Pearson, A Dominant eukaryotic export production during ocean anoxic events reflects 
the importance of recycled $\mathrm{NH}_{4}{ }^{+}$. Proc. Natl Acad. Sci. USA 109, 2269-2274 (2012).

42. Kashiyama, Y., Ogawa, N. O., Kuroda, J. \& Shiro, M. Diazotrophic cyanobacteria as the major photoautotrophs during mid-Cretaceous oceanic anoxic events: nitrogen and carbon isotopic evidence from sedimentary porphyrin. Org. Geochem. 39, 532-549 (2008).

43. Junium, C. K., Freeman, K. H. \& Arthur, M. A. Controls on the stratigraphic distribution and nitrogen isotopic composition of zinc, vanadyl and free base porphyrins through Oceanic Anoxic Event 2 at Demerara Rise. Org. Geochem. 80, 60-71 (2015).

44. Junium, C. K. \& Arthur, M. A. Nitrogen cycling during the Cretaceous, Cenomanian-Turonian Oceanic Anoxic Event II. Geochem. Geophys. Geosyst. 8, Q03002 (2007).

45. Fruedenthal, T., Wagner, T., Wenzhofer, F., Zabel, M. \& Wefer, G. Early diagenesis of organic matter from sediments of the eastern subtropical Atlantic: evidence from stable nitrogen and carbon isotopes. Geochim. Cosmochim. Acta 65, 1795-1808 (2001).

46. Junium, C. K., Arthur, M. A. \& Freeman, K. H. Compound-specific $\delta^{15} \mathrm{~N}$ and chlorin preservation in surface sediments of the Peru Margin with implications for ancient bulk $\delta^{15} \mathrm{~N}$ records. Geochim. Cosmochim. Acta 160, 306-318 (2015).

47. Higgins, M. B., Robinson, R. S., Carter, S. J. \& Pearson, A. Evidence from chlorin nitrogen isotopes for alternating nutrient regimes in the Eastern Mediterranean Sea. Earth Planet. Sci. Lett. 290, 102-107 (2010).

48. Ruvalcaba Baroni, I. et al. The nitrogen isotope composition of sediments from the proto-North Atlantic during Oceanic Anoxic Event 2. Paleoceanography 2, 923-937 (2015).

49. Khozyem, H., Adatte, T., Spangenberg, J. E., Tantawy, A. A. \& Keller, G. Palaeoenvironmental and climatic changes during the Palaeocene-Eocene Thermal Maximum (PETM) at the Wadi Nukhul Section, Sinai, Egypt. J. Geol. Soc. Lond. 170, 341-352 (2013).

50. Knies, J., Mann, U., Popp, B. N. \& Stein, R. Surface water productivity and paleoceanographic implications in the Cenozoic Arctic Ocean. Paleoceanography 23, 1-12 (2008).

51. Flores, E., Frias, J. E., Rubio, L. M. \& Herrero, A. Photosynthetic nitrate assimilation in cyanobacteria. Photosynth. Res. 83, 117-133 (2005).

52. Yakushev, E. V. et al. Analysis of the water column oxic/anoxic interface in the Black and Baltic seas with a numerical model. Mar. Chem. 107, 388-410 (2007).

53. Velinsky, D. J. \& Fogel, M. L. Cycling of dissolved and particulate nitrogen and carbon in the Fremvaren Fjord, Norway: stable isotopic variations. Mar. Chem. 67, 161-180 (1999).

54. Boyer, D. L. \& Droser, M. L. Palaeoecological patterns within the dysaerobic biofacies: examples from Devonian black shales of New York state. Palaeogeogr. Palaeoclimatol. Palaeoecol. 276, 206-216 (2009).

55. Codispoti, L. A. Interesting times for marine $\mathrm{N}_{2} \mathrm{O}$. Science 327, 1339-1341 (2010).

56. Bange, H. W. Nitrogen in the Marine Environment (2008).

57. Goreau, T. J., Kaplan, W. A. \& Wofsy, S. C. Production of $\mathrm{NO}_{2}{ }^{-}$and $\mathrm{N}_{2} \mathrm{O}$ by nitrifying bacteria at reduced concentrations of oxygen. Appl. Environ. Microbiol. 40, 526-532 (1980).

58. Löscher, C. R. et al. Production of oceanic nitrous oxide by ammoniaoxidizing archaea. Biogeosciences 9, 2419-2429 (2012).

59. Naqvi, S. W. A., Bange, H. W. \& Far, L. Marine hypoxia/anoxia as a source of $\mathrm{CH}_{4}$ and $\mathrm{N}_{2} \mathrm{O}$. Biogeosciences 7, 2159-2190 (2010).

60. Naqvi, S. W. A. et al. Increased marine production of $\mathrm{N}_{2} \mathrm{O}$ due to intensifying anoxia on the Indian continental shelf. Nature 408, 346-349 (2000).

61. Myllykangas, J. P. et al. Effects of the 2014 major Baltic inflow on methane and nitrous oxide dynamics in the water column of the central Baltic Sea. Earth Syst. Dyn. 8, 817-826 (2017)

62. Jenkyns, H. C. Geochemistry of oceanic anoxic events. Geochem. Geophys. Geosyst. 11, Q03004 (2010).

63. Trabucho Alexandre, J. et al. The mid-Cretaceous North Atlantic nutrient trap: black shales and OAEs. Paleoceanography 25, 1-14 (2010).

64. Polissar, P. J., Fulton, J. M., Junium, C. K., Turich, C. C. \& Freeman, K. H. Measurement of ${ }^{13} \mathrm{C}$ and ${ }^{15} \mathrm{~N}$ isotopic composition on nanomolar quantities of C and N. Anal. Chem. 81, 755-763 (2009).
65. Coplen, T. B. et al. New guidelines for $\delta^{13} \mathrm{C}$ measurements. Anal. Chem. 78, 2439-2441 (2006)

66. Scotese, C. R. Atlas of Paleogene Paleogeographic Maps. PALEOMAP Project (2014).

67. Knox, R. W. O. et al. The Qreiya section at Gebel Abu Had: lithostratigraphy, clay mineralogy, geochemistry and biostratigraphy. Micropaleontology 49, 93-104 (2003).

68. Giusberti, L. et al. Mode and tempo of the Paleocene-Eocene thermal maximum in an expanded section from the Venetian pre-Alps. Bull. Geol. Soc. Am. 119, 391-412 (2007).

69. Junium, C. K., Meyers, S. R. \& Arthur, M. A. Nitrogen cycle dynamics in the Late Cretaceous Greenhouse. Earth Planet. Sci. Lett. 1, 1-11 (2017).

70. Jenkyns, H. C., Matthews, A., Tsikos, H. \& Erel, Y. Nitrate reduction, sulfate reduction, and sedimentary iron isotope evolution during the Cenomanian-Turonian oceanic anoxic event. Paleoceanography 22, 1-17 (2007).

71. Jenkyns, H. C., Gröcke, D. R. \& Hesselbo, S. P. Nitrogen isotope evidence for water mass denitrification during the early Toarcian (Jurassic) oceanic anoxic event. Paleoceanography 16, 593-603 (2001).

72. Kuypers, M. M. M., van Breugel, Y., Schouten, S., Erba, E. \& Damsté, J. S. S. $\mathrm{N}_{2}$-fixing cyanobacteria supplied nutrient $\mathrm{N}$ for Cretaceous oceanic anoxic events. Geology 32, 853-856 (2004).

73. Dumitrescu, M. \& Brassell, S. C. Compositional and isotopic characteristics of organic matter for the early Aptian Oceanic Anoxic Event at Shatsky Rise, ODP Leg 198. Palaeogeogr. Palaeoclimatol. Palaeoecol. 235, 168-191 (2006).

\section{Acknowledgements}

E. Shcherbinina and Y. Gavrilov provided access to the Kheu River section. Funding was provided by NSF EAR-1455258 to C.K.J.

\section{Author contributions}

C.K.J. designed the research. A.J.D. provided samples. C.K.J. and B.T.U. conducted geochemical analyses. C.K.J., A.J.D., and B.T.U. analyzed the data and equally contributed to the preparation of the manuscript.

\section{Additional information}

Supplementary Information accompanies this paper at https://doi.org/10.1038/s41467 018-05486-w.

Competing interests: The authors declare no competing interests.

Reprints and permission information is available online at http://npg.nature.com/ reprintsandpermissions/

Publisher's note: Springer Nature remains neutral with regard to jurisdictional claims in published maps and institutional affiliations.

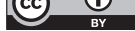

Open Access This article is licensed under a Creative Commons Attribution 4.0 International License, which permits use, sharing, adaptation, distribution and reproduction in any medium or format, as long as you give appropriate credit to the original author(s) and the source, provide a link to the Creative Commons license, and indicate if changes were made. The images or other third party material in this article are included in the article's Creative Commons license, unless indicated otherwise in a credit line to the material. If material is not included in the article's Creative Commons license and your intended use is not permitted by statutory regulation or exceeds the permitted use, you will need to obtain permission directly from the copyright holder. To view a copy of this license, visit http://creativecommons.org/ licenses/by/4.0/.

(C) The Author(s) 2018 